\title{
Variability in trophic level and habitat use in response to environmental forcing: isotopic niche dynamics of breeding seabirds in the southeastern Bering Sea
}

\author{
Alexis P. Will*, Alexander S. Kitaysky \\ Institute of Arctic Biology, University of Alaska Fairbanks, Fairbanks, AK 99775, USA
}

\begin{abstract}
Climate-driven changes in the marine environment may affect inter- and intraspecific resource partitioning by marine organisms. When and how resources are partitioned may depend on access to diverse foraging habitats. Here we examined the variability in the isotopic niche of breeding seabirds with respect to trophic level and habitat use in years with cold and warm sea temperatures in the Bering Sea. Between 1999 and $2015(\mathrm{n}=12 \mathrm{yr})$, we collected blood from blacklegged kittiwakes Rissa tridactyla, and common Uria aalge and thick-billed murres U. lomvia breeding on St. George and St. Paul Islands on the southeastern Bering Sea continental shelf. We examined isotopic niche dynamics at the group and species levels. Stable isotope values of blood tissues corroborated published observations of seabird distributions in the region. All 3 species increased foraging on shelf-based prey during warm oceanographic conditions, in contrast to a higher reliance on oceanic-based prey during cold conditions. Under warm ocean conditions, the isotopic niche of the seabird group with access to only shelf habitat (St. Paul Island) contracted, whereas the isotopic niche of the seabird group with access to shelf, slope, and basin habitats (St. George Island) expanded. These group-level responses were associated with increased food availability. We conclude that habitat heterogeneity in the vicinity of breeding colonies may mediate how predators partition food resources in response to changes in climate-driven food availability.
\end{abstract}

KEY WORDS: Black-legged kittiwake - Murre - Stable Isotope Bayesian Ellipses in R - SIBER · Layman's metrics $\cdot$ Stable isotope analysis $\cdot$ Habitat heterogeneity $\cdot$ Resource partitioning

\section{INTRODUCTION}

The southeastern Bering Sea is characterized by long- and short-term variability in oceanographic conditions. On a decadal scale, the region as a whole may be subject to either a warmer or a colder climate regime (Stabeno et al. 2012). On shorter temporal scales (1 to $3 \mathrm{yr}$ ), the region shifts between cold years, characterized by extensive sea ice and a late sea ice retreat, and warm years, characterized by low sea ice coverage and an early retreat (Stabeno et al. 2012). Fluctuations in annual sea ice extent and the timing of its retreat have been linked to the timing and duration of primary production

\footnotetext{
${ }^{*}$ Corresponding author: awill4@alaska.edu
}

(Liu et al. 2016), and the availability of large lipidrich crustacean zooplankton over the shelf (e.g. Hunt et al. 2016, Sigler et al. 2016). It has been proposed that these oscillating oceanographic conditions affect the distribution and availability of forage fish to marine predators, including seabirds (Hunt et al. 2011). This well studied system provides a natural setting in which to address how sub-Arctic species may respond to future changes in the marine environment. We used it to examine how seabirds use and partition resources during a period when the southeastern Bering Sea experienced very cold and very warm years (1999-2016, Overland et al. 2012, Stabeno et al. 2012).

() The authors 2018. Open Access under Creative Commons by Attribution Licence. Use, distribution and reproduction are unrestricted. Authors and original publication must be credited. 
Resource partitioning is considered to be an important mechanism by which species are able to reduce competition for common resources and co-exist (Schoener 1974, Finke \& Snyder 2008). The partitioning of food resources in the ocean may be dynamic, driven by environmental factors affecting the availability of prey (e.g. Friedlaender et al. 2011, Sabarros et al. 2012). In seabirds, sympatrically breeding species are known to partition resources horizontally (Cherel et al. 2008, Rayner et al. 2016), vertically (Navarro et al. 2015, Kokubun et al. 2016), diurnally (Barger et al. 2016), and/or by prey type (Moreno et al. 2016, Rayner et al. 2016) or size (Mancini \& Bugoni 2014). The degree of partitioning can depend upon changes in food availability (Barger \& Kitaysky 2012), or it can occur during energetically taxing life stages such as offspring provisioning (Cherel et al. 2008, 2014, Barger et al. 2016, Delord et al. 2016).

Habitat heterogeneity may also affect resource partitioning. Access to different types of habitat may reduce interspecific competition for resources. For example, when foraging in a complex habitat, stone crabs Menippe mercernaria and knobbed whelks Busycon carica maintain consumption rates and feed upon similar prey species because these 2 predators are able to forage in different types of habitat (Hughes \& Grabowski 2006). How access to diverse foraging habitats may modify interspecific resource partitioning under different environmental conditions in seabirds is, however, not well known.

Seabirds in the southeastern Bering Sea have access to different types of habitat depending on where they breed (Fig. 1). St. Paul Island, part of the Pribilof Islands, supports a relatively small (31000 black-legged kittiwakes Rissa tridactyla ['kittiwakes'], 39000 common murres Uria aalge, and 115000 thick-billed murres $U$. lomvia) multi-species seabird colony located on the continental shelf. In contrast, St. George Island supports a multi-species colony that is an order of magnitude larger (72 000 kittiwakes, 190000 common murres, and 1500000 thick-billed murres) (Hickey \& Craighead 1977). By being closer to the shelf edge than St. Paul Island, St. George Island affords seabirds easier access to shelf, slope, and basin foraging habitats. These 2 islands are located $60 \mathrm{~km}$ apart (Byrd et al. 2008a). Tracking studies have revealed that murres and kittiwakes rarely forage in the area between the 2 colonies, and that there is little overlap in their shelf and slope foraging locations (Harding et al. 2013, Paredes et al. 2014, Kokubun et al. 2018 in this Theme Section).

Stable isotope analysis is a non-invasive tool that can be used to identify shifts in diet (e.g. Karnovsky et al. 2008, Cherel et al. 2014, Kowalczyk et al. 2015) and to determine how sympatric species partition prey resources (e.g. Young et al. 2010, Barger \& Kitaysky 2012, Jaeger et al. 2014). Stable isotope ratios capitalize on the differential rate that heavy and light non-decaying isotopes of elements are used in biological processes. By analyzing samples for carbon and nitrogen isotopic ratios we can construct a predator's isotopic niche (Bearhop et al. 2004, Newsome et al. 2007), which describes where (reflected in carbon, $\delta^{13} \mathrm{C}$ ) and at what trophic level (reflected in

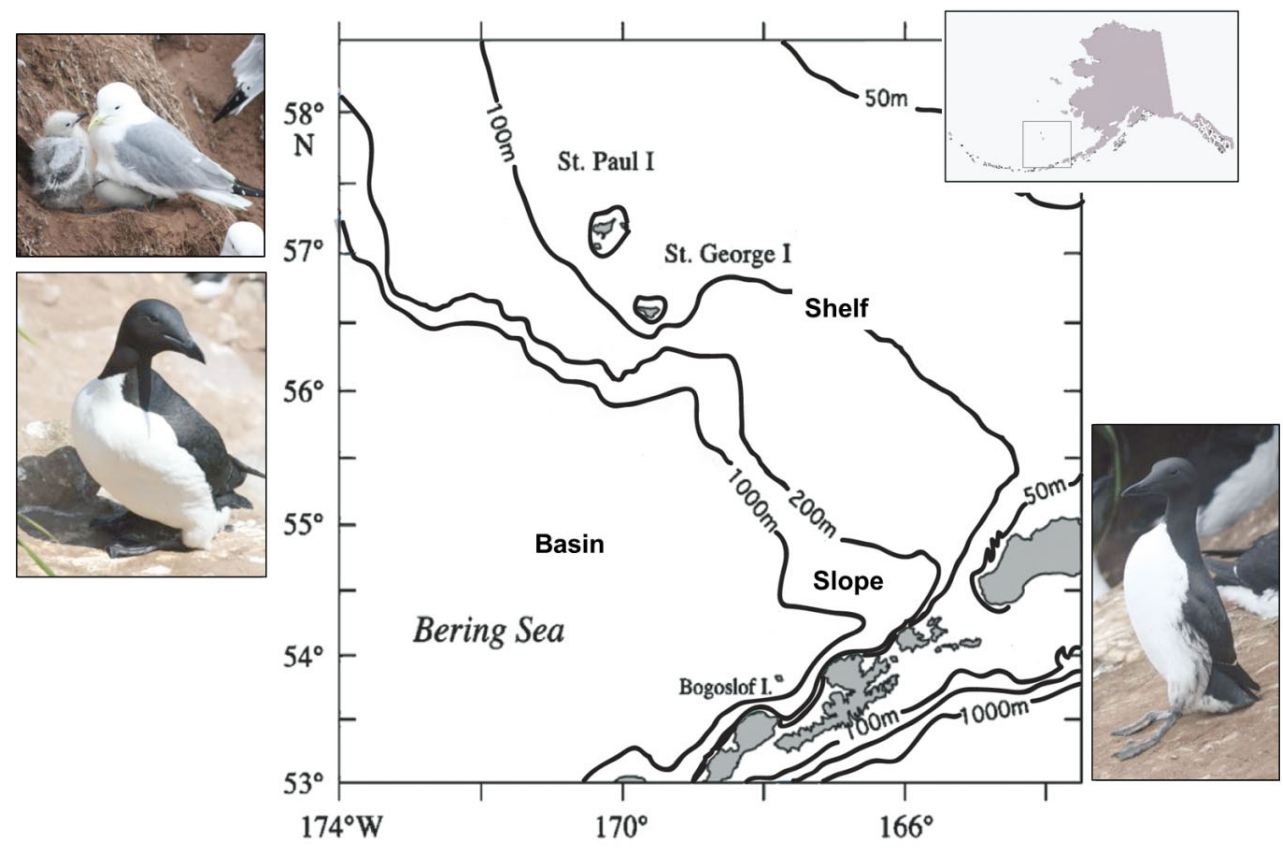

Fig. 1. Study area and focal species. St. Paul and St. George Islands are located on the continental shelf, 90 and $25 \mathrm{~km}$ from the shelf break, respectively. Pictured clockwise from top left are a blacklegged kittiwake Rissa tridactyla with chick, a common murre Uria aalge, and a thick-billed murre U. lomvia (photo credit: A. Will, map adapted from Hunt et al. 2008) 
nitrogen, $\delta^{15} \mathrm{~N}$ ) it has been foraging (Hobson et al. 1994). Isotopic niches have proven useful in discerning ecological segregation of marine species (e.g. tuna, Ménard et al. 2007; dolphins, Gross et al. 2009; myctophids, Cherel et al. 2010), mapping food webs (e.g. Linnebjerg et al. 2016), and inferring food web diversity (e.g. Yurkowski et al. 2016).

Using blood samples collected over the past $16 \mathrm{yr}$, we examined the isotopic niche dynamics of 3 piscivorous seabird species breeding on the Pribilof Islands to determine whether and how oceanographic conditions and habitat heterogeneity affected interspecific prey resource partitioning. The foraging behavior of seabirds is known to change throughout the course of the breeding season in response to the demands of their offspring (Navarro et al. 2014, Barger et al. 2016) as well as changes in prey resources (Scioscia et al. 2014, Jakubas et al. 2016). We analyzed tissues with different turnover rates to characterize the arrival (early) and chickrearing (late) periods of the breeding season to capture seasonal prey-use dynamics.

We included 3 seabird species (1 kittiwake and 2 murre species, which we refer to as a 'group', Fig. 1) that use different parts of the horizontal and vertical foraging space. Black-legged kittiwakes are able to travel far from the breeding colony (up to $200 \mathrm{~km}$, Paredes et al. 2014) at relatively low costs, yet as surface feeders, they have limited access to deeper layers of the water column. Common and thick-billed murres are, compared to kittiwakes, restricted in the distance they can travel from the colony (no more than $20 \mathrm{~km}$ during chick-provisioning day trips, but up to $100 \mathrm{~km}$ during overnight trips, Paredes et al. 2015). Both murres are pursuit-diving foragers and have access to prey throughout the water column, up to $200 \mathrm{~m}$ in depth (Croll et al. 1992, Orben et al. 2015). Common murres, compared to thick-billed murres, are able to fly greater distances, and the 2 species partition their use of the water column by time of day, distance from the breeding colony, and by foraging depth (Barger et al. 2016, Kokubun et al. 2016).

In cold years, murres and kittiwakes breeding on the Pribilof Islands incurred relatively high levels of nutritional stress, suggesting that food was scarce or difficult to obtain (Paredes et al. 2012, Satterthwaite et al. 2012, Kokubun et al. 2018). In warm years, however, they had relatively low levels of nutritional stress, indicating that food was abundant or more easily obtained (Benowitz-Fredericks et al. 2008, Satterthwaite et al. 2012, Harding et al. 2013, Paredes et al. 2014). When conditions are warm, the southeastern Bering Sea shelf supports large cohorts of young- of-the-year walleye pollock Gadus chalcogramma that remain in the upper water column (top $20 \mathrm{~m}$ ) until early autumn (Moss et al. 2009, Hunt et al. 2011, Hunt et al. 2018 in this Theme Section). These small fish can make up a large portion of murre and kittiwake diets at the Pribilof Islands (Renner et al. 2012, Sinclair et al. 2008). In cold years, young-of-the-year walleye pollock may be less plentiful in the upper water column (Moss et al. 2009, Hunt et al. 2011, Renner et al. 2016, Hunt et al. 2018). Thus, we predicted that the isotopic niche of seabirds would vary between cold and warm conditions in response to changes in prey availability.

In the southeastern Bering Sea, there is a $\delta^{13} \mathrm{C}$ gradient in seabird prey: prey from the continental shelf have higher $\delta^{13} \mathrm{C}$ values compared to alternative prey from the continental slope or ocean basin (Zeppelin et al. 2015), which is also reflected in the stable isotope ratios of bird blood tissues (Dorresteijn et al. 2012). In cold conditions, when juvenile pollock are relatively scarce on the shelf, we predicted that the isotopic niche of birds with access primarily to shelf foraging habitat (St. Paul Island) would expand as species separate themselves by prey type and geographic location. In cold years, St. Paul Island kittiwakes have been observed to forage near the continental slope and in the ocean basin (Paredes et al. 2014), while murres continued to forage on the shelf near the breeding colonies (Harding et al. 2013, Paredes et al. 2015). In contrast, we predicted that the isotopic niche used by seabirds on colonies closer to the shelf break would contract during cold years. On St. George Island, all species have access to more heterogeneous foraging habitat, so during cold ocean conditions when prey availability is low on the shelf, we expected seabirds to concentrate their foraging efforts on prey inhabiting the continental slope region (Pomerleau et al. 2014, Zeppelin et al. 2015, Suryan et al. 2016).

\section{MATERIALS AND METHODS}

\section{Study sites and sample collection}

Murres and kittiwakes were captured using noose poles on St. Paul $\left(57.18119^{\circ} \mathrm{N}, 170.266^{\circ} \mathrm{W}\right)$ and St. George $\left(56.580507^{\circ} \mathrm{N}, 169.605925^{\circ} \mathrm{W}\right)$ Islands between 1 July and 25 August (see Table 1 for years and sample sizes). No more than $1 \mathrm{ml}$ of blood was collected from the alar vein and stored on ice (for details see Benowitz-Fredericks et al. 2008). Within $12 \mathrm{~h}$ of collection, blood was separated via centri- 
Table 1. Sample sizes by year, island, and tissue. All except 2015 plasma values are from individuals whose red blood cells were also analyzed. BLKI = black-legged kittiwake Rissa tridactyla, COMU = common murre Uria aalge, TBMU = thick-billed murre $U$. lomvia

\begin{tabular}{|c|c|c|c|c|c|c|c|}
\hline \multirow[t]{2}{*}{ Year } & \multirow[t]{2}{*}{ Island } & \multicolumn{3}{|c|}{ Red blood cells } & \multirow[b]{2}{*}{ BLKI } & \multicolumn{2}{|l|}{ Plasma } \\
\hline & & BLKI & COMU & TBMU & & COMU & TBMU \\
\hline \multirow[t]{2}{*}{1999} & St. George & - & 10 & 10 & - & - & - \\
\hline & St. Paul & 10 & - & 10 & 9 & - & 7 \\
\hline \multirow[t]{2}{*}{2003} & St. George & 30 & 21 & 30 & 8 & 8 & 9 \\
\hline & St. Paul & 30 & 18 & 30 & 10 & 8 & 10 \\
\hline \multirow[t]{2}{*}{2004} & St. George & 28 & 26 & 30 & 8 & 10 & 10 \\
\hline & St. Paul & 31 & 24 & 25 & 10 & 8 & 10 \\
\hline \multirow[t]{2}{*}{2005} & St. George & 26 & 18 & 29 & 7 & 9 & 9 \\
\hline & St. Paul & 15 & 8 & 18 & 5 & 2 & 7 \\
\hline \multirow[t]{2}{*}{2006} & St. George & - & - & 22 & - & - & - \\
\hline & St. Paul & - & - & - & - & - & - \\
\hline \multirow[t]{2}{*}{2007} & St. George & - & - & 32 & - & - & - \\
\hline & St. Paul & - & - & - & - & - & - \\
\hline \multirow[t]{2}{*}{2008} & St. George & 31 & 22 & 27 & 10 & 10 & 10 \\
\hline & St. Paul & 30 & 28 & 30 & 10 & 10 & 10 \\
\hline \multirow[t]{2}{*}{2009} & St. George & 26 & 37 & 28 & 9 & 10 & 10 \\
\hline & St. Paul & 24 & 26 & 30 & 10 & 10 & 10 \\
\hline \multirow[t]{2}{*}{2010} & St. George & 36 & - & 33 & 10 & - & 9 \\
\hline & St. Paul & 35 & - & 39 & 10 & - & 10 \\
\hline \multirow[t]{2}{*}{2013} & St. George & - & - & - & - & - & 30 \\
\hline & St. Paul & - & - & - & - & - & - \\
\hline \multirow[t]{2}{*}{2014} & St. George & - & 14 & 38 & - & 14 & 18 \\
\hline & St. Paul & - & - & - & - & - & - \\
\hline \multirow[t]{2}{*}{2015} & St. George & - & - & - & - & 15 & 20 \\
\hline & St. Paul & - & - & - & - & - & - \\
\hline \multirow[t]{2}{*}{ Totals } & St. George & 177 & 148 & 279 & 52 & 76 & 125 \\
\hline & St. Paul & 175 & 104 & 182 & 64 & 38 & 64 \\
\hline
\end{tabular}

rearing' stage). Individual's $\delta^{15} \mathrm{~N}$ values for red blood cell and plasma samples were not correlated $(\mathrm{r}=0.086)$ and $\delta^{13} \mathrm{C}$ were only moderately positively correlated $(\mathrm{r}=0.46)$.

Red blood cells have a C:N ratio resembling pure protein (about 3.5, Cherel et al. 2014); therefore, no lipid extraction prior to analysis was needed. We freeze-dried a $20 \mu$ sub-sample of red blood cells and weighed 0.1 to $0.6 \mathrm{mg}$ into a tin boat for analysis. Plasma samples have a relatively high lipid content, which depletes ${ }^{13} \mathrm{C}$ and may lead to spurious results (Hobson \& Clark 1992, Post et al. 2007). We delipidated a $20 \mu \mathrm{l}$ sub-sample of plasma using a 1:4 methanol:choloroform solution (as described by Barger et al. 2016). Post-delipidation, we freeze-dried samples and weighed 0.1 to $0.6 \mathrm{mg}$ into a tin boat for analysis. For delipidated samples where $\mathrm{C}: \mathrm{N}$ ratios remained relatively high (>4, Cherel et al. 2005), we used the equation for aquatic organisms described by Post et al. (2007) to correct for carbon depletion $\left(\Delta^{13} \mathrm{C}=-3.32+0.99 \times \mathrm{C}: \mathrm{N}\right.$, where $\Delta^{13} \mathrm{C}$ is the correction factor applied to the $\delta^{13} \mathrm{C}$ values).

Samples were analyzed at the University of Alaska Fairbanks Stable Isotope Facility (UAF SIF). Tin boats were loaded into an Elemental Analyzer (EA Costech ESC 4010) and processed via continuous flow isotope ratio mass spectrometry using a Delta+XP isotope ratio mass spectrometer. Ratios of ${ }^{15} \mathrm{~N}:{ }^{14} \mathrm{~N}$ and ${ }^{13} \mathrm{C}:{ }^{12} \mathrm{C}$ were calibrated using an internal standard (peptone: replicate measures indicated measurement errors of

fugation into plasma and red blood cells, and then stored frozen until further analysis.

\section{Stable isotope analysis}

We used the isotopic composition of red blood cells and plasma to characterize seabird diets for the duration of the breeding season. Red blood cells reflect the diet of birds during the 2 mo (Hobson \& Clark 1993) prior to the sampling date; thus our red blood cell samples captured the diets of birds arriving at the colony and initiating their clutches (hereafter referred to as the 'arrival' stage). Plasma turns over more quickly (5 to 7 d, Hobson \& Clark 1993) and reflects an individual's diet during the week prior to the sampling date (hereafter referred to as the 'chick$\pm 0.34 \%$ and $\pm 0.08 \%$ for $\delta^{13} \mathrm{C}$ and $\delta^{15} \mathrm{~N}$, respectively) and then compared to the international standard ratios of atmospheric nitrogen and Vienna Pee Dee Belemnite using $\delta X=\left[\left(\mathrm{R}_{\text {sample }} / \mathrm{R}_{\text {standard }}\right)-1\right] \times 1000$, where $X$ is ${ }^{15} \mathrm{~N}$ or ${ }^{13} \mathrm{C}$ and $\mathrm{R}$ is the ratio of heavy:light nitrogen or carbon. Results are expressed in delta notation as parts per thousand (Peterson \& Fry 1987).

\section{Statistical analysis}

We conducted all statistical analysis in R (v. 3.2.3, R Core Development Team 2015 and v 3.4.2, R Core Development Team 2017). To determine whether years in our study had 'warm' or 'cold' oceanographic conditions, we used principal components analysis (prcomp package, R Core Development Team 2015) 
to assign a continuous value to each year based on measurements from 5 climate indices. We included the summer Pacific Decadal Oscillation index (PDOs, averaged for June, July, and August, www.bering climate.noaa.gov/data/), which captures the variability in sea surface temperature across the North Pacific; the ice cover index (ICI, www.beringclimate.noaa. gov/data/), the average ice concentration January to May reported as anomalies against the long-term mean; the ice retreat index (IRI, www.beringclimate. noaa.gov/data/), the number of days after March 15 when $>10 \%$ of ice disappears from near mooring M2; and the sea surface and bottom temperature (SST and Bottom) within a $150 \mathrm{~km}$ radius of the Pribilof Islands (Lauth 2016). These variables were selected to capture large and small scale variability and have been shown to be biologically relevant (seabirds: Dorresteijn et al. 2012, Satterthwaite et al. 2012; zooplankton and fish: Stabeno et al. 2012).

Prior to examining isotopic niche dynamics, we modeled $\delta^{13} \mathrm{C}$ and $\delta^{15} \mathrm{~N}$ as a function of oceanographic conditions, colony, species, and season. The purpose for this was 2-fold: (1) to verify that changes in oceanographic conditions correspond to changes in $\delta^{15} \mathrm{~N}$ or $\delta^{13} \mathrm{C}$ values; and (2) to determine how the models should be built to best describe the isotopic niche dynamics in the region. If, for example, all species in both colonies responded to oceanographic conditions similarly during both the arrival and chick-rearing period, then we would model the isotopic niches in a single model, not differentiating between colony or time during the breeding season. On the other hand, if interaction terms indicated that species responded differently on different islands and under different oceanographic conditions then we would model the isotopic niche by species, oceanographic condition, and island. We used a random intercept mixed model (lme4 package, Bates et al. 2015) and maximum likelihood estimation to model $\delta^{13} \mathrm{C}$ and $\delta^{15} \mathrm{~N}$ separately with respect to the 2 islands (fixed effect: Colony), species (fixed effect: Species), time of the breeding season (fixed effect: Season), and oceanographic conditions (fixed effect: PC1, each year had a score). We included 2-way interaction terms and verified that candidate models did not include terms with high collinearity among non-categorical variables (vif.mer function available at https://github.com/aufrank/R-hacks/blob/master/ mer-utils.R, cut-off value $=3$ ). Since plasma and red blood samples were obtained from the same individuals, we included individual as a random factor. We included the 2-way interactions of these variables to determine whether species from different colonies behaved similarly (indicated by non-significant interaction terms) under different oceanographic conditions and/or across a breeding season. We used the corrected Akaike's information criterion $\left(\mathrm{AIC}_{\mathrm{c}}\right.$ for small sample sizes, Burnham \& Anderson 2002) to select the best candidate model, which we used to determine how to structure our analysis of the isotopic niche dynamics (see Tables S1 \& S2 in the Supplement at www.int-res.com/articles/suppl/m592 p247_supp.pdf). We also calculated the means and standard errors for $\delta^{13} \mathrm{C}$ and $\delta^{15} \mathrm{~N}$ values of each species data to capture shifts in the isotopic niche at the species level.

We used the R package SIBER (Jackson et al. 2011) to analyze the stable isotope data at the group and species level. We used a Bayesian approach to calculate Layman's metrics, a set of summary statistics that describe changes in the shape, size, and concentration of points within the isotopic ellipse (Layman et al. 2007) for the combined group of seabirds. We used this same approach to calculate the $40 \%$ standard ellipse area (SEA) for each individual species under different oceanographic conditions during arrival and chick rearing, which we used for graphing purposes only. We categorized years as 'warm' or 'cold' according to our principal components analysis (described above) and included them in the model as the 'community' variable (i.e. all warm years were combined and all cold years were combined). We ran a Markov chain Monte Carlo with 3 chains drawing from a Wishart distribution, with vague normal priors, for 50000 iterations, and a burn in of 10000 . Every 20th value of the posterior was retained (Jackson et al. 2011, Parnell et al. 2013). Following Jackson et al. (2011), we report the Layman's metrics for the group-level analysis including the mode, and $50 \%$ and $90 \%$ credible intervals for the total isotopic area covered as described by the $\mathrm{d} x_{-}$range $(\mathrm{dC})$ and $d y \_$range $(d N)$, which give the range of the group along the $x$ - $\left(\delta^{13} C\right)$ and $y$-axes $\left(\delta^{15} \mathrm{~N}\right)$, the distance to the centroid (Centroid), and the average distance to a point's nearest neighbor (NNdist). In regards to ecological interpretations: $\mathrm{dN}$ provides a description of trophic diversity and $\mathrm{dC}$ characterizes the breadth of the food web's base. The SEA.B is an estimate of the core $40 \%$ isotopic niche used by the group or species and is considered to be robust in the face of small sample sizes. 'Centroid' is a measure of the average diversity used in the food web. 'NNdist' complements Centroid by reporting the distribution of species within the total area, with a small NNdist indicating that species are foraging in a similar isotopic space. 


\section{RESULTS}

\section{Principal components analysis of climate variables}

The first principal component (PC1) retained $91.34 \%$ of the variance in the component variables. All 5 components were loaded for PC1 (PDO = 0.906, $\mathrm{ICI}=-0.982$, IRI $=-0.98$, Bottom $=0.951, \mathrm{SST}=$ 0.957 ), and contributed a similar amount to determining the score $(\mathrm{PDO}=17.968, \mathrm{ICI}=21.135$, IRI $=$ 21.019, Bottom $=19.803, \mathrm{SST}=20.075)$. The designation of 'warm' and 'cold' years based on PC1 corresponded to characterizations of the study years in the literature (Fig. 2, Stabeno et al. 2012).

\section{Mixed model results}

During warm conditions, all 3 species on both colonies foraged on more shelf-based prey; however, the relative change in carbon stable isotope ratios differed among species (Table 2, see Table S3 in the Supplement) being greatest in common murres (PC1 $\times$ Species $F_{2,28}=28.255, \mathrm{p}<0.0001$, Fig. 3). Birds breeding on St. George relied more heavily on oceanic prey species compared to St. Paul birds, a difference more pronounced during arrival than during chick-rearing $\left(\right.$ Season $\times$ Colony $F_{1,502}=19, \mathrm{p}<0.0001$, Fig. 3)

Nitrogen stable isotope ratios also changed in response to warmer conditions (Table 3, see Table S4 in the Supplement); however, the direction of the change varied between arrival and chick-rearing

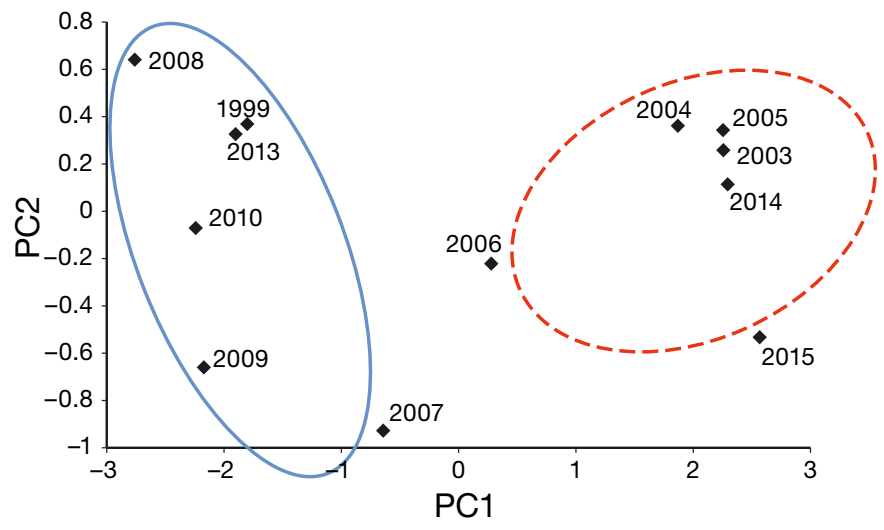

Fig. 2. Categorization of years as 'cold' or 'warm' using PC1 (the first principal component). Negative numbers correspond to cold oceanographic conditions, and positive numbers correspond to warm oceanographic conditions. PC1 is plotted against PC2 (the second principal component). The $68 \%$ ellipses indicate the cold (solid blue line) and warm (dashed red line) groupings. The year corresponding to each point is noted within the plot
$\left(\mathrm{PC} 1 \times\right.$ Season $\left.F_{1,1041}=26.14, \mathrm{p}<0.0001\right)$ and among species $\left(\mathrm{PC} 1 \times\right.$ Species $\left.F_{2,1242}=18.19, \mathrm{p}<0.0001\right)$. For example, $\delta^{15} \mathrm{~N}$ increased in warm compared to cold conditions during chick-rearing but remained the same regardless of ocean conditions during arrival. At the species level, without taking breeding colony into account, $\delta^{15} \mathrm{~N}$ for common murres increased in warm ocean conditions, whereas the $\delta^{15} \mathrm{~N}$ for kittiwakes and thick-billed murres remained similar between warm and cold ocean conditions. Similarly, only common murres showed a decrease in $\delta^{15} \mathrm{~N}$ from arrival to chick-rearing, whereas kittiwakes and thick-billed murres had similar $\delta^{15} \mathrm{~N}$ throughout the breeding season (Season $\times$ Species $F_{2,1000}=18.04$, p $<$ $0.0001)$, again without taking into account the breeding colony. Birds breeding on St. Paul Island fed on prey with higher $\delta^{15} \mathrm{~N}$ than birds breeding on St. George Island (Colony $F_{1,1209}=358.26, \mathrm{p}<0.0001$, Fig. 3).

\section{Group analysis}

The isotopic niche of breeding seabirds on St. George Island was larger during warm conditions (P[SEA.B cold < SEA.B warm $]=1$ for both arrival and chick-rearing), and especially so early in the breeding season (Fig. 4A). In warm conditions, trophic level diversity increased (dN, Fig. 4A), as did the overall diversity of the utilized food web (Centroid mode $[95 \% \mathrm{CI}]$, cold $=0.26[0.172,0.358]$, warm $=$ $0.601[0.482,0.716])$.

The isotopic niche of seabirds breeding on St. Paul Island had the opposite response to warmer ocean conditions (Fig. 4C,D). Under warm ocean conditions, birds tended to forage on a smaller diversity of basal resources, likely reflecting a constricted geographic range (dC, Fig. 4C). During chick rearing, the isotopic niche of St. Paul Island breeding seabirds was smaller in warm compared to cold ocean conditions (P[SEA.B cold > SEA.B warm = 1]), which was characterized by a decrease in the diversity of trophic levels utilized (dN, Fig. 4D), and a consolidation of the foraging area (dC, Fig. 4D). Trophic diversity decreased during warm ocean conditions (Centroid, cold $=0.709[0.529,0.909]$, warm $=0.277[0.108$, 0.523]) and the trophic niche of individual species tended to converge (NNdist, cold $=0.889$ [0.581, $0.909]$, warm $=0.355$ [0.116, 0.696]). In general, birds on St. Paul Island utilized a less diverse and smaller isotopic niche in warm ocean conditions than birds on St. George Island (see Table S5 in the Supplement for full Layman's metrics). 
Table 2. Corrected Akaike's information criterion $\left(\mathrm{AIC}_{\mathrm{c}}\right)$ model selection results for $\delta^{13} \mathrm{C}$. We report the top 2 models, as well as the single variable models and additive model. All other models had an $\mathrm{AIC}_{\mathrm{c}}$ weight $\left(w_{\mathrm{i}}\right)$ of 0 . We tested 38 models. All models include bird as a random effect. A summary for the top model (Table S3) as well as a full list of the candidate models

(Table S1) are reported in the Supplement (www.int-res.com/articles/suppl/m593p247_supp.pdf)

\begin{tabular}{|c|c|c|c|c|}
\hline Carbon models & $k$ & $\mathrm{AIC}_{\mathrm{C}}$ & $\Delta \mathrm{AIC}_{\mathrm{c}}$ & $w_{\mathrm{i}}$ \\
\hline PC $1+$ Species + Season + Colony + PC $1 \times$ Species + Season $\times$ Colony & 11 & 2776.95 & 0.00 & 1.000 \\
\hline PC1 + Species + Colony + Season + PC $1 \times$ Species & 10 & 2794.11 & 17.16 & 0.000 \\
\hline PC1 + Species + Colony + Season & 8 & 2847.39 & 70.44 & 0.000 \\
\hline PC1 & 4 & 3066.71 & 289.75 & 0.000 \\
\hline Colony & 4 & 3087.00 & 310.05 & 0.000 \\
\hline Species & 5 & 3166.42 & 389.46 & 0.000 \\
\hline Season & 4 & 3185.67 & 408.72 & 0.000 \\
\hline Null model & 3 & 3193.26 & 416.31 & 0.000 \\
\hline
\end{tabular}
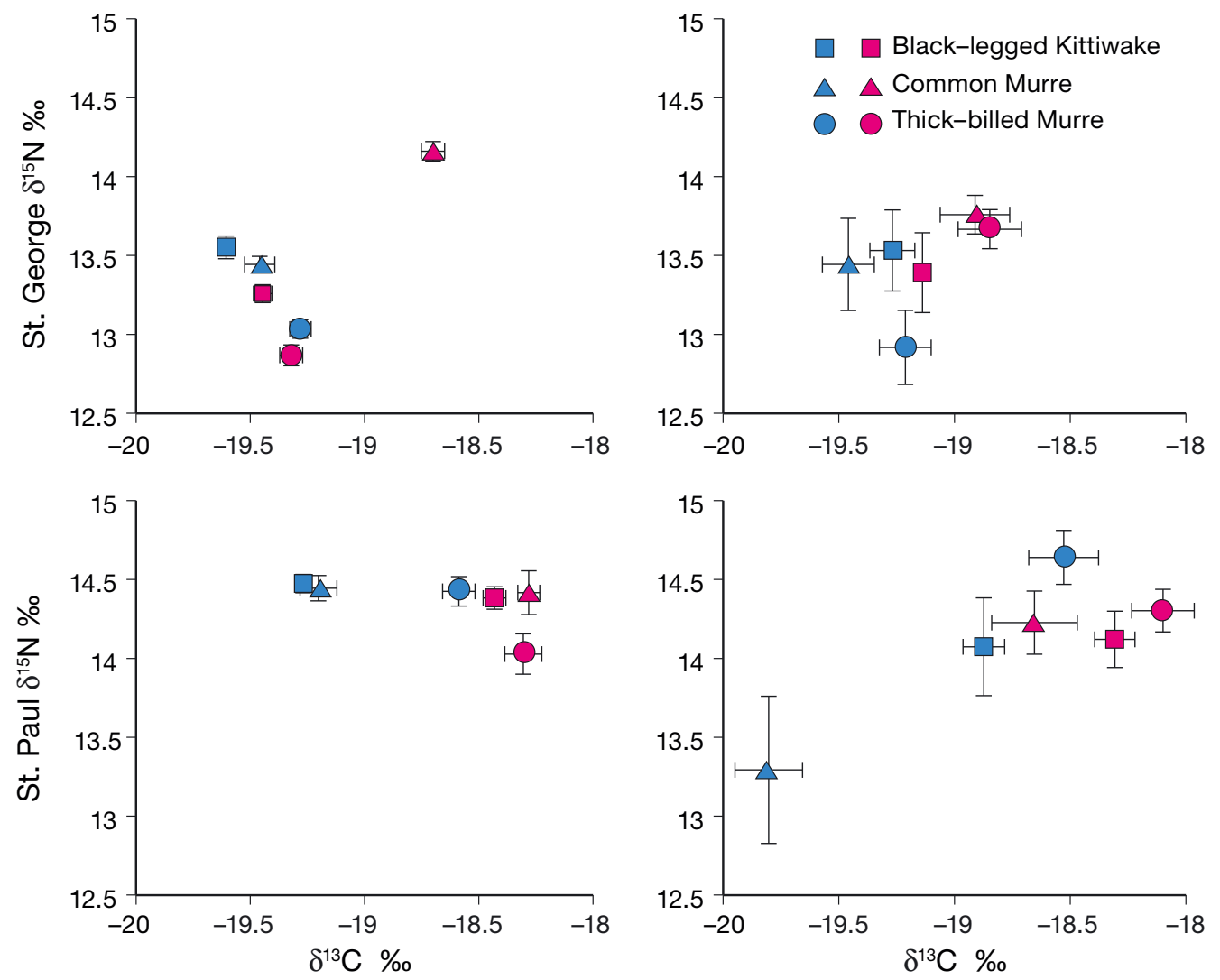

Fig. 3. Average stable isotope values for species breeding on St. George (top panel) and St. Paul (bottom panel) Islands. Mean $( \pm \mathrm{SE})$ isotopic signatures of black-legged kittiwakes Rissa tridactyla and murres Uria aalge and U. lomvia shifted between cold (blue symbols) and warm (red symbols) oceanographic conditions and between the arrival (left column) and chick-rearing (right column) periods of the breeding season

\section{Species analysis}

In support of the group level analysis, St. George Island common murres had a larger niche in warm compared to cold ocean conditions (P [SEA.B cold $<$ SEA.B warm] = 1 and 0.99 for arrival and chick-rearing, respectively). However, the isotopic niche of thick- billed murres and kittiwakes was smaller in warm compared to cold conditions (P[SEA.B cold > SEA.B warm] $=0.96,1$, and 0.6 for kittiwakes, thick-billed murres arrival, and thick-billed murres chick-rearing, respectively, Fig. 5). Seasonal dynamics of niche size differed between warm and cold ocean conditions. In warm years, the isotopic niche for all species in- 
Table 3. Corrected Akaike's information criterion $\left(\mathrm{AIC}_{\mathrm{c}}\right)$ model selection results for $\delta^{15} \mathrm{~N}$. We report the top 2 models, as well as the single variable models and additive model. All other models had an $\mathrm{AIC}_{\mathrm{c}}$ weight $\left(w_{\mathrm{i}}\right)$ of 0 . We tested 41 models. All models include bird as a random effect. A summary for the top model (Table S4) as well as a full list of the candidate models (Table S2) are reported in the Supplement

\begin{tabular}{|c|c|c|c|c|}
\hline Nitrogen models & $k$ & $\mathrm{AIC}_{\mathrm{c}}$ & $\Delta \mathrm{AIC}_{\mathrm{c}}$ & $W_{\mathrm{i}}$ \\
\hline PC1 + Season + Species + Colony + PC1 $\times$ Season + PC1 $\times$ Species + Season $\times$ Species & 13 & 3984.43 & 0.00 & 0.992 \\
\hline Season + Species + Colony + Season $\times$ Species + Colony $\times$ Species + Season $\times$ Colony & 12 & 3993.95 & 9.53 & 0.008 \\
\hline PC1 + Species + Colony + Season & 8 & 4066.14 & 81.72 & 0.000 \\
\hline Colony & 4 & 4110.83 & 126.41 & 0.000 \\
\hline Species & 5 & 4349.44 & 365.01 & 0.000 \\
\hline Null model & 3 & 4391.72 & 407.29 & 0.000 \\
\hline Season & 4 & 4392.07 & 407.65 & 0.000 \\
\hline PC1 & 4 & 4393.64 & 409.22 & 0.000 \\
\hline
\end{tabular}
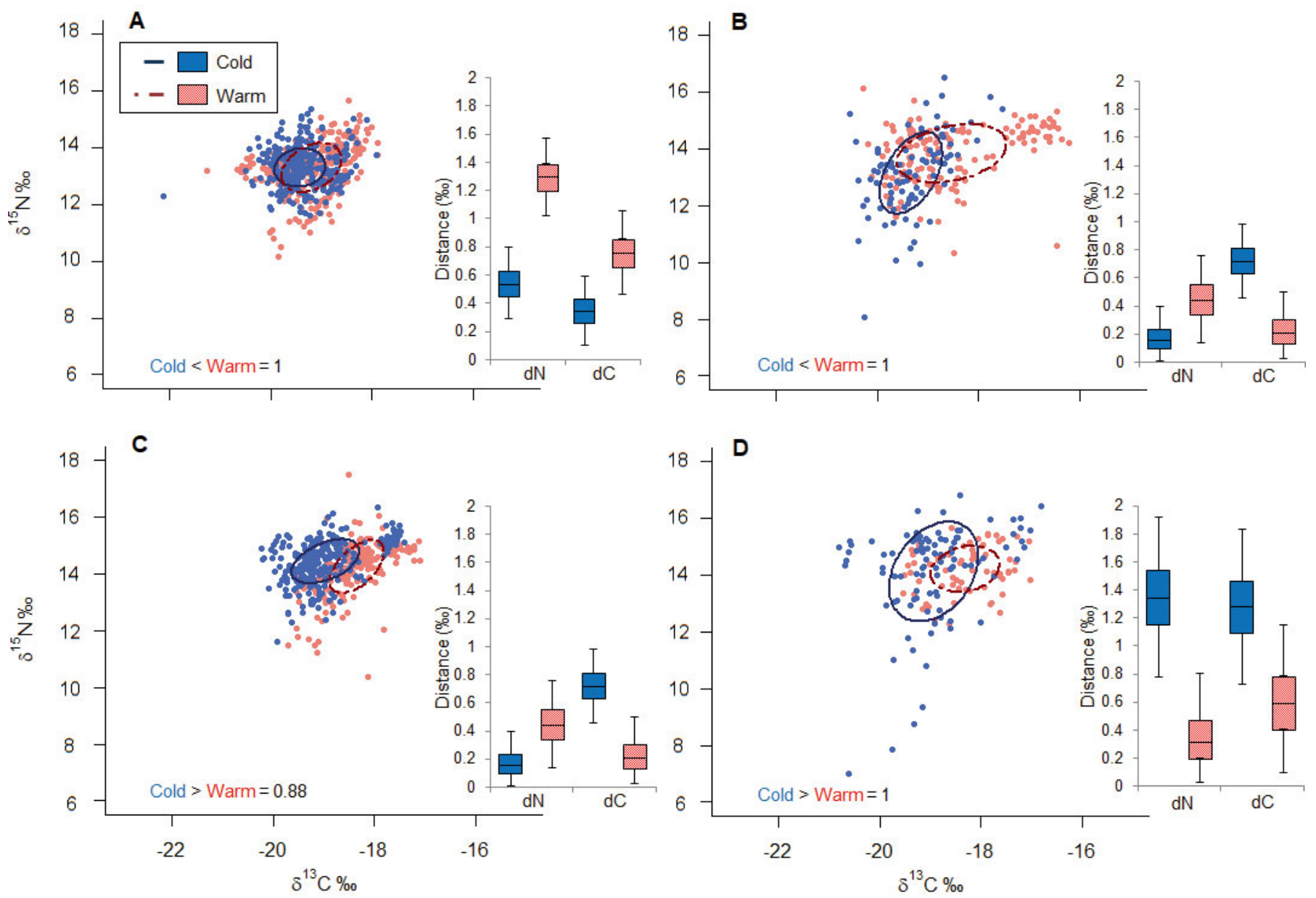

Fig. 4. Changes in the isotopic niche of black-legged kittiwakes Rissa tridactyla and murres Uria aalge and U. lomvia between cold and warm conditions on (A) St. George Island during arrival, (B) St. George Island during chick-rearing, (C) St. Paul Island during arrival, and (D) St. Paul Island during chick-rearing. The raw data are displayed as cold (blue points) and warm (red points), overlaid with the $40 \%$ ellipses of the seabird group in cold (blue solid line) and warm (red dashed line) ocean conditions. The posterior modes, and $50 \%$ (box) and 95\% (whisker) credible intervals of the Layman's metrics $\mathrm{dN}$ and $\mathrm{dC}$ of the seabird group for cold (blue) and warm (red) ocean conditions are displayed in the inset. See 'Materials and methods' for a description of parameters; a complete set of Layman's metrics can be found in 

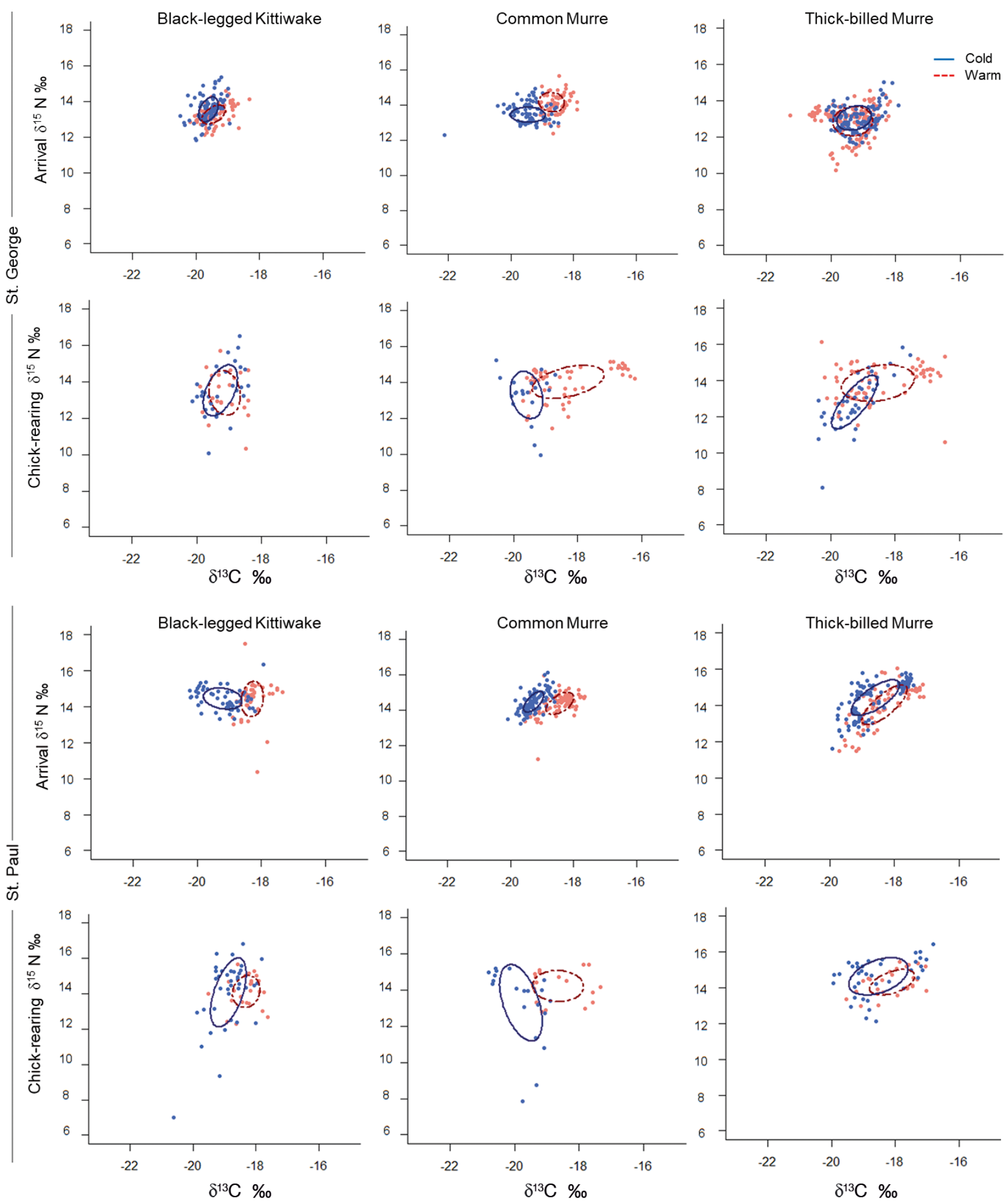

Fig. 5. Stable isotope signatures of red blood cells ('Arrival') and plasma ('Chick-rearing') for black-legged kittiwakes Rissa tridactyla and murres Uria aalge and U. lomvia breeding on St. George and St. Paul Islands in cold (blue) and warm (red) conditions. Superimposed are the $40 \%$ ellipses for each species during cold (blue solid line) and warm (red dashed line) conditions; a complete set of Bayesian standard ellipse areas (SEA.B) can be found in Table S6 in the Supplement 
creased in size during chick-rearing compared to arrival (P[SEA.B warm-arrival < SEA.B warm-chickrearing] $=0.97,0.99$, and 0.55 thick-billed murres, respectively), while in cold years, the niche size was smaller during chick-rearing compared to arrival (P $[$ SEA.B cold-arrival > SEA.B cold-chick-rearing] $=$ 0.92, 0.88, 1 for kittiwakes, common murres, and thick-billed murres, respectively, Fig. 5, see Table S6 in the Supplement for SEA.B modes and CI).

On St. Paul Island, almost all birds had smaller isotopic niches in warm compared to cold ocean conditions (P[SEA.B cold > SEA.B warm] $=0.97$ to 1 ) with 2 exceptions: common murres during arrival and thick-billed murres during chick-rearing had larger isotopic niches in warm compared to cold ocean conditions (P[SEA.B cold < SEA.B warm] = 1 and 0.89 for common murres arrival and thick-billed murres chick-rearing, respectively). Seasonal changes in isotopic niche size were nearly consistent across oceanographic conditions and species. Niches during chick-rearing were larger than during arrival (P [SEA.B arrival < SEA.B chick-rearing] $=0.87$ to 1 ) with 1 exception: kittiwakes during warm years had a smaller isotopic niche during chick-rearing compared to arrival (P[SEA.B arrival > SEA.B chick-rearing] $=0.99$, Fig. 5).

\section{DISCUSSION}

The diets of murres and black-legged kittiwakes have been documented to be diverse, including forage fish and invertebrate species (Iverson et al. 2007, Sinclair et al. 2008, Renner et al. 2012). To date, however, efforts to detect broad relationships in this region between the diet of murres and kittiwakes nesting at the Pribilof Islands and regional climate indices have failed to find any consistent trends (Renner et al. 2012, 2014, but see Kokubun et al. 2018 for thick-billed murres). In contrast, shifting patterns in habitat use have been documented from ship-based surveys at both seasonal and inter-annual time scales (Schneider \& Hunt 1984, Hunt et al. 2014, Renner et al. 2016, Suryan et al. 2016, Hunt et al. 2018). To advance the understanding of how seabirds nesting on the Pribilof Islands alter their foraging between warm and cold years, we characterized the isotopic niche of black-legged kittiwakes and common and thick-billed murres breeding on St. Paul and St. George Islands. It is expected that species engaging in similar foraging modes will partition prey when interspecific competition is more likely to occur (during food shortages or chick-rearing), and consume similar prey when it is plentiful (Hardin 1960, e.g. Barger et al. 2016). We investigated how food resources were partitioned among 3 seabird species under different oceanographic conditions and with access to different habitat types. We predicted that during cold ocean conditions, when food is less available, the diet among species would differ more than in warm ocean conditions when prey is abundant. We further predicted that this pattern of partitioning would be most apparent in seabirds breeding on St. Paul Island, a colony with more limited access to diverse foraging habitats.

\section{Effect of oceanographic conditions on diet}

Seabirds breeding on both St. Paul and St. George Islands shifted to consuming more shelf-based prey under warm oceanographic conditions. At-sea surveys have indicated that surface-feeding blacklegged kittiwakes and moderately deep-diving shearwaters Ardenna spp. occurred in greater abundance over the shelf region in warm years (Renner et al. 2016). This may have been a response to an increased abundance of juvenile pollock on the shelf in warm years (Hunt et al. 2011, Renner et al. 2016, Suryan et al. 2016). In years with early sea ice retreat and warm sea temperatures, juvenile pollock have been observed closer to the ocean surface and found to occur at 51 times the densities recorded in cold years (Renner et al. 2016). Whether a greater abundance of pollock is also beneficial for murres has been unclear, as water masses and prey at depth may be somewhat independent of the dynamics shaping the food web available to surface foragers (Byrd et al. 2008b, Renner et al. 2016). Our results, however, indicate that common and thick-billed murres shifted towards shelf-based prey on St. George and St. Paul Islands, suggesting that they may also be feeding on juvenile pollock in warm years (Sinclair et al. 2008, Kokubun et al. 2018). Although all 3 species in both colonies took advantage of more abundant shelf-based prey in warm years in some way, we found that isotopic niche dynamics in the 2 colonies were different between warm and cold years and among species.

\section{Isotopic niche dynamics of the seabird group}

The combined isotopic niche of black-legged kittiwakes and murres nesting on St. Paul Island was heavily influenced by ocean conditions. In warm years, the group's niche area was smaller during 
arrival and chick-rearing. However, the diversity in foraging locations during arrival in warm conditions was comparable to that in cold conditions, as reflected in the $\mathrm{dN}$ and $\mathrm{dC}$ isotopic distances. This may be a signal that the food web on the shelf develops from a common starting point early in the breeding season, but that the trajectory of development may be determined by oceanographic conditions that result in an increasingly different foraging landscape as the season progresses (Hunt et al. 2011). Unfortunately we do not have baseline $\delta^{13} \mathrm{C}$ or $\delta^{15} \mathrm{~N}$ values which could be used to determine whether changes in isotopic distances are due to the number of sources in a food web, to food web diversity, or simply to a relatively small plasma sample size (Layman et al. 2012, Brind'Amour \& Dubois 2013). While our ability to infer inter-seasonal food web structure is limited, we found no year-associated patterns within the warm or cold isotopic values; therefore, we are able to discount the possibility that changes in baseline values alone explain the shifts in the use of the isotopic space we observed.

In warm years, the isotopic space used by seabirds on St. George Island, which is closer to the shelf break, was more diverse and larger than the isotopic space used by seabirds on St. Paul Island, which is situated farther from the shelf break. In contrast, the total isotopic spaces used at the 2 islands were similar in cold years. This may be partially attributed to the differences in colony size between the 2 islands. St. George Island supports an order of magnitude more seabirds than St. Paul Island (Hickey \& Craighead 1977). Due to the population size, breeding seabirds on St. George Island may continue to use slope/ oceanic foraging habitat during warm years, when shelf food resources are abundant, to avoid intraspecific competition on the shelf. The isotopic niche dynamics suggest that generalist seabirds breeding on St. George Island used oceanic-based prey, both during warm conditions when alternative shelfbased prey was available, and especially in cold conditions when it was not. The analysis of stomach contents and tracking data collected from adult birds corroborate our finding that the slope/oceanic region provides an important prey-base for St. George Island seabirds irrespective of environmental conditions (Sinclair et al. 2008, Renner et al. 2012, Harding et al. 2013). Despite the continued use of slope/ oceanic prey in warm years, fledging success of thick-billed murres on both islands has been positively correlated with the occurrence of coastal/ shelf-based species in chick diets (Renner et al. 2014), which may be due to the energetic savings parents make by being able to capture prey closer to the colony (Pennycuick 1997, Elliott et al. 2013).

\section{Species level responses}

In cold conditions on St. Paul Island, the trophic diversity at the species level generally increased over the course of the breeding season (i.e. the isotopic niche was larger during chick-rearing than arrival). A similar pattern of larger isotopic space utilization was also observed for seabirds breeding on St. George Island during warm ocean conditions. Intraspecific diet diversification during chick-rearing appears to have occurred and may have been due to seasonal changes in prey type and/or availability (Darimont \& Reimchen 2002), or the result of an increase in energy demands associated with chickrearing, which may lead to increased partitioning in prey among breeding seabirds (Barger et al. 2016). Alternatively, this pattern may be attributed to the development of the food web and subsequent changes in prey isotopic values as the productive season progressed rather than an actual change in types of prey consumed. If this is the case, it would still indicate that, under these conditions, the type of prey consumed by species was diverse, as prey isotopic values became more different (the niche area expanded) as the breeding season progressed.

In contrast, the isotopic area utilized by kittiwakes on St. Paul Island in warm conditions was smaller during chick-rearing than arrival. This was also observed for all 3 study species breeding on St. George Island during cold ocean conditions. A decrease in the isotopic space used over the course of the breeding season may be attributed to a reliance on more similar prey species during chick-rearing than arrival. While there may be seasonal changes in the isotopic values of prey, if murres and kittiwakes were relying on the same species throughout the breeding season we would expect there to be no difference in the size of the isotopic niche between arrival and chick-rearing.

On St. George Island, in warm ocean conditions, access to diverse habitat and the availability of onshelf young-of-the-year pollock may facilitate prey resource partitioning (Darimont et al. 2009). During warm conditions on St. George Island, the isotopic niche of murres and kittiwakes expanded compared to cold conditions, indicating that while birds used on-shelf prey, this did not replace the use of oceanicbased prey (dC was larger in warm compared to cold conditions, Fig. 5). 


\section{Closing remarks}

To summarize, we found that during warm years, piscivorous seabirds consumed prey on the shelf that was not available to them during cold years. In addition, species with access to multiple habitat types (e.g. those breeding on St. George Island) were able to exploit additional prey sources in the vicinity of their breeding colony. Consuming more prey on the shelf would potentially reduce the cost of foraging for adults during the chick-rearing period (Kokubun et al. 2018). While warm conditions in early summer have been linked to abundant young-of-the-year pollock in the upper water column of the shelf (Renner et al. 2016), warm conditions in late summer and autumn result in low recruitment of the same young pollock (Hunt et al. 2011, Mueter et al. 2011). Thus, although warm conditions may currently be associated with high prey availability near the breeding colonies, an increase in the frequency of warm years may eventually result in a negative impact on seabirds through reduced pollock populations (Mueter et al. 2011).

More generally, we demonstrated that the isotopic niche can be used to characterize how seabirds with different foraging strategies and diverse diets partition the foraging landscape in response to environmental variability. In this study, we specifically addressed whether or not having access to diverse foraging habitat modifies how seabirds partition prey resources under different oceanographic conditions. We found that knowledge of habitat type, and how prey dynamics in different habitats may change, is needed in order to correctly interpret the expansion or contraction of the isotopic niche used by a group of species as a response to changes in prey availability. In regards to the southeastern Bering Sea specifically, we conclude that changes in oceanographic conditions influenced the isotopic niche of piscivorous seabirds and that this response was mediated by foraging habitat heterogeneity.

Acknowledgements. This work could not have been completed without the collection, preparation, or analysis of samples as part of other research over the past $16 \mathrm{yr}$. We thank (alphabetically) Yumi Arumitzu, Allison Banks, Chris Barger, Morgan Benowitz-Fredericks, Tom Dempsey, Ine Dorresteijn, Brie Drummond, Abram Fleishman, Motohiro Ito, Sara Iverson, Dale Kikuchi, Zhenya Kitaiskaia, Nobuo Kokubun, Rachael Orben, John Piatt, Rosana Paredes, Nobuhiro Sato, Michael Shultz, Alan Springer, Akinori Takahashi, Shiway Wang, Takashi Yamamoto, Rebecca Young, and Sarah Youngren. Stable isotope analysis of plasma samples was funded by a Calvin J Lensink Fellowship awarded to A.P.W. and was completed by Tim Howe and Norma Haubenstock at the Alaska Stable Isotope Facility. Red blood cell stable isotope analysis was conducted as part of the North Pacific Research Board's (NPRB) Bering Sea Integrated Ecosystem Research Project \#67 and 77 awarded to A.S.K. Input from G. Breed, G. Hunt, A. Powell, A. Springer, and 3 anonymous reviewers greatly improved the manuscript. All samples were collected under the required permits from the US Fish and Wildlife Service and Alaska Department of Fish and Game with the approval of the University of Alaska Fairbanks' Institutional Animal Care and Use Committee. This is NPRB publication \#660.

\section{LITERATURE CITED}

Barger CP, Kitaysky AS (2012) Isotopic segregation between sympatric seabird species increases with nutritional stress. Biol Lett 8:442-445

Barger CP, Young RC, Will A, Ito M, Kitaysky AS (2016) Resource partitioning between sympatric seabird species increases during chick- rearing. Ecosphere 7:e01447

* Bates D, Maechler M, Bolker B, Walker S (2015) Fitting linear mixed-effects models using lme4. J Stat Softw 67:1-48

* Bearhop S, Adams CE, Waldron S, Fuller RA, Macleod H (2004) Determining trophic niche width: a novel approach using stable isotope analysis. J Anim Ecol 73:1007-1012

* Benowitz-Fredericks ZM, Shultz MT, Kitaysky AS (2008) Stress hormones suggest opposite trends of food availability for planktivorous and piscivorous seabirds in 2 years. Deep Sea Res II 55:1868-1876

* Brind'Amour A, Dubois SF (2013) Isotopic diversity indices: How sensitive to food web structure? PLOS ONE 8:e84198

Burnham KP, Anderson DR (2002) Model selection and multimodal inference: a practical information-theoretic approach. Springer-Verlag, New York

* Byrd GV, Schmutz JA, Renner HM (2008a) Contrasting population trends of piscivorous seabirds in the Pribilof Islands: a 30-year perspective. Deep Sea Res II 55:1846-1855

*Byrd GV, Sydeman WJ, Renner HM, Minobe S (2008b) Responses of piscivorous seabirds at the Pribilof Islands to ocean climate. Deep Sea Res II 55:1856-1867

Cherel Y, Hobson KA, Weimerskirch H (2005) Using stable isotopes to study resource acquisition and allocation in procellariiform seabirds. Oecologia 145:533-540

* Cherel Y, Le Corre M, Jaquemet S, Ménard F, Richard P, Weimerskirch $H$ (2008) Resource partitioning within a tropical seabird community: new information from stable isotopes. Mar Ecol Prog Ser 366:281-291

* Cherel Y, Fontaine C, Richard P, Labatc JP (2010) Isotopic niches and trophic levels of myctophid fishes and their predators in the Southern Ocean. Limnol Oceanogr 55: 324-332

* Cherel Y, Connan M, Jaeger A, Richard P (2014) Seabird year-round and historical feeding ecology: blood and feather $\delta^{13} \mathrm{C}$ and $\delta^{15} \mathrm{~N}$ values document foraging plasticity of small sympatric petrels. Mar Ecol Prog Ser 505:267-280

C Croll DA, Gaston AJ, Bureber AE, Konnoff D (1992) Foraging behavior and physiological adaptation for diving in thick-billed murres. Ecology 73:344-356

* Darimont CT, Reimchen TE (2002) Intra-hair stable isotope analysis implies seasonal shift to salmon in gray wolf diet. Can J Zool 80:1638-1642

* Darimont CT, Paquet PC, Reimchen TE (2009) Landscape heterogeneity and marine subsidy generate extensive intrapopulation niche diversity in a large terrestrial ver- 
tebrate. J Anim Ecol 78:126-133

Delord K, Pinet P, Pinaud D, Barbaud C and others (2016) Species-specific foraging strategies and segregation mechanisms of sympatric Antarctic fulmarine petrels throughout the annual cycle. Ibis 158:569-586

Dorresteijn I, Kitaysky AS, Barger C, Benowitz-Fredericks ZM, Byrd GV, Shultz M, Young R (2012) Climate affects food availability to planktivorous least auklets Aethia pusilla through physical processes in the southeastern Bering Sea. Mar Ecol Prog Ser 454:207-220

Elliott KH, Ricklefs RE, Gaston AJ, Hatch SA, Speakman JR, Davoren GK (2013) High flight costs, but low dive costs, in auks support the biomechanical hypothesis for flightlessness in penguins. Proc Natl Acad Sci USA 110: 9380-9384

Finke DL, Snyder WE (2008) Niche partitioning increases resource exploitation by diverse communities. Science 321:1488-1490

Friedlaender AS, Johnston DW, Fraser WR, Burns J, Patrick NH, Costa DP (2011) Ecological niche modeling of sympatric krill predators around Marguerite Bay, western Antarctic Peninsula. Deep Sea Res II 58:1729-1740

* Gross A, Kiszka J, Van Canneyt O, Richard P, Ridoux V (2009) A preliminary study of habitat and resource partitioning among co-occurring tropical dolphins around Mayotte, southwest Indian Ocean. Estuar Coast Shelf Sci 84:367-374

Hardin G (1960) The competitive exclusion principle. Science 131:1292-1297

Harding A, Paredes R, Suryan R, Roby D and others (2013) Does location really matter? An inter-colony comparison of seabirds breeding at varying distances from productive oceanographic features in the Bering Sea. Deep Sea Res II 94:178-191

Hickey JJ, Craighead FL (1977) A census of seabirds on the Pribilof Islands. In: Environmental Assessment of the Alaskan Continental Shelf. Annual Reports of Principal Investigators, Vol 2. BLM/NOAA/OMPA, Boulder, CO, p 96-195

Hobson KA, Clark RG (1992) Assessing avian diets using stable isotopes I: Turnover of ${ }^{13} \mathrm{C}$ in tissues. Condor 94: 181-188

Hobson KA, Clark RG (1993) Turnover of ${ }^{13} \mathrm{C}$ in cellular and plasma fractions of blood: implications for nondestructive sampling in avian dietary studies. Auk 110:638-641

Hobson KA, Piatt JF, Pitocchelli J (1994) Using stable isotopes to determine seabird trophic relationships. J Anim Ecol 63:786-798

Hughes AR, Grabowski JH (2006) Habitat context influences predator interference interactions and the strength of resource partitioning. Oecologia 149:256-264

Hunt GL Jr, Stabeno PJ, Strom S, Napp JM (2008) Patterns of spatial and temporal variation in the marine ecosystem of the southeastern Bering Sea, with special reference to the Pribilof Domain. Deep-Sea Res 55:1919-1944

*Hunt GL Jr, Coyle KO, Eisner LB, Farley EV and others (2011) Climate impacts on eastern Bering Sea foodwebs: a synthesis of new data and an assessment of the Oscillating Control Hypothesis. ICES J Mar Sci 68:1230-1243

Hunt GL Jr, Renner M, Kuletz K (2014) Seasonal variation in the cross-shelf distribution of seabirds in the southeastern Bering Sea. Deep Sea Res II 109:266-281

Hunt GL Jr, Ressler PH, Gibson GA, De Robertis A and others (2016) Euphausiids in the eastern Bering Sea: A synthesis of recent studies of euphausiid production, consumption and population control. Deep Sea Res II 134:204-222
Hunt GL, Renner M, Kuletz KJ, Salo S (2018) Timing of seaice retreat affects the distribution of seabirds and their prey in the southeastern Bering Sea. Mar Ecol Prog Ser 593:209-230

* Iverson SJ, Springer AM, Kitaysky AS (2007) Seabirds as indicators of food web structure and ecosystem variability: qualitative and quantitative diet analyses using fatty acids. Mar Ecol Prog Ser 352:235-244

* Jackson AL, Inger R, Parnell AC, Bearhop S (2011) Comparing isotopic niche widths among and within communities: SIBER - Stable Isotope Bayesian Ellipses in R. J Anim Ecol 80:595-602

Jaeger A, Goutte A, Lecomte VJ, Richard P and others (2014) Age, sex, and breeding status shape a complex foraging pattern in an extremely long-lived seabird. Ecology 95: 2324-2333

* Jakubas D, Wojczulanis-Jakubas K, Boehnke R, Kidawa D, Błachowiak-Samołyk K, Stempniewicz L (2016) Intraseasonal variation in zooplankton availability, chick diet and breeding performance of a high Arctic planktivorous seabird. Polar Biol 39:1547-1561

K Karnovsky NJ, Hobson KA, Iverson S, Hunt GL Jr (2008) Seasonal changes in diets of seabirds in the North Water Polynya: a multiple-indicator approach. Mar Ecol Prog Ser 357:291-299

Kokubun N, Yamamoto T, Sato N, Watanuki Y, Will A, Kitaysky AS, Takahashi A (2016) Foraging segregation of two congeneric diving seabird species breeding on St. George Island, Bering Sea. Biogeosciences Discuss 13: 2579-2591

Kokubun N, Takahashi A, Paredes R, Young RC, and others (2018) Inter-annual climate variability affects foraging behavior and nutritional state of thick-billed murres breeding in the southeastern Bering Sea. Mar Ecol Prog Ser 593:195-208

Kowalczyk ND, Reina RD, Preston TJ, Chiaradia A (2015) Environmental variability drives shifts in the foraging behaviour and reproductive success of an inshore seabird. Oecologia 178:967-979

Lauth B (2016) Eastern Bering Sea trawl data. National Oceanic and Atmospheric Administration, Seattle, WA

K Layman CA, Arrington DA, Montaña CG, Post DM (2007) Can stable isotope ratios provide for community-wide measures of trophic structure? Ecology 88:42-48

*Layman CA, Araujo MS, Boucek R, Hammerschlag-Peyer CM and others (2012) Applying stable isotopes to examine food web structure: an overview of analytical tools. Biol Rev Camb Philos Soc 87:545-562

Linnebjerg JF, Hobson KA, Fort J, Nielsen TG and others (2016) Deciphering the structure of the West Greenland marine food web using stable isotopes $\left(\delta^{13} \mathrm{C}, \delta^{15} \mathrm{~N}\right)$. Mar Biol 163:230

* Liu CL, Zhai L, Zeemand SI, Eisner LB and others (2016) Seasonal and geographic variations in modeled primary production and phytoplankton losses from the mixed layer between warm and cold years on the eastern Bering Sea shelf. Deep Sea Res II 134:141-156

*Mancini PL, Bugoni L (2014) Resource partitioning by seabirds and their relationship with other consumers at and around a small tropical archipelago. ICES J Mar Sci 71: 2599-2607

Ménard F, Lorrain A, Potier M, Marsac F (2007) Isotopic evidence of distinct feeding ecologies and movement patterns in two migratory predators (yellowfin tuna and swordfish) of the western Indian Ocean. Mar Biol 153:141-152 
Moreno R, Stowasser G, McGill RAR, Bearhop S, Phillips RA (2016) Assessing the structure and temporal dynamics of seabird communities: the challenge of capturing marine ecosystem complexity. J Anim Ecol 85:199-212

Moss JH, Farley EV Jr, Feldman AM, Ianeli JN (2009) Spatial distribution, energetic status, and food habits of Eastern Bering Sea age-0 walleye pollock. Trans Am Fish Soc 138:497-505

* Mueter FJ, Bond NA, Ianelli JN, Hollowed AB (2011) Expected declines in recruitment of walleye pollock (Theragra chalcogramma) in the eastern Bering Sea under future climate change. ICES J Mar Sci 68:1284-1296

Navarro J, Moreno R, Braun L, Sanpera C, Hennicke JC (2014) Resource partitioning between incubating and chick-rearing brown boobies and red-tailed tropicbirds on Christmas Island. Zool Stud 53:27

* Navarro J, Cardador L, Brown R, Phillips RA (2015) Spatial distribution and ecological niches of non-breeding planktivorous petrels. Sci Rep 5:12164

Newsome SD, Marinez del Rio C, Bearhop S, Phillips DL (2007) A niche for isotopic ecology. Front Ecol Environ 5: 429-436

Orben RA, Paredes R, Roby DD, Irons DB, Shaffer SA (2015) Body size affects individual winter foraging strategies of thick-billed murres in the Bering Sea. J Anim Ecol 84: 1589-1599

* Overland JE, Wang M, Wood KR, Percival DB, Bond NA (2012) Recent Bering Sea warm and cold events in a 95year context. Deep Sea Res II 65-70:6-13

* Paredes R, Harding AMA, Irons DB, Roby DD and others (2012) Proximity to multiple foraging habitats enhances seabirds' resilience to local food shortages. Mar Ecol Prog Ser 471:253-269

* Paredes R, Orben RA, Suryan RM, Irons DB and others (2014) Foraging responses of black-legged kittiwakes to prolonged food shortages around colonies on the Bering Sea shelf. PLOS ONE 9:e92520

Paredes R, Orben RA, Roby DD, Irons DB and others (2015) Foraging ecology during nesting influences body size in a pursuit-diving seabird. Mar Ecol Prog Ser 533: 261-276

Parnell AC, Phillips DL, Bearhop S, Semmens BX and others (2013) Bayesian stable isotope mixing models. Environmetrics 24:387-399

* Pennycuick C (1997) Actual and 'optimum' flight speeds: field data reassessed. J Exp Biol 200:2355-2361

Peterson BJ, Fry B (1987) Stable isotopes in ecosystem studies. Annu Rev Ecol Syst 18:293-320

Pomerleau C, Nelson RJ, Hunt BPV, Sastri AR, Williams W (2014) Spatial patterns in zooplankton communities and stable isotope ratios $\left(\delta^{13} \mathrm{C}\right.$ and $\left.\delta^{15} \mathrm{~N}\right)$ in relation to oceanographic conditions in the sub-Arctic Pacific and western Arctic regions during the summer of 2008. J Plankton Res 36:757-775

* Post DM, Layman CA, Arrington DA, Takimoto G, Quattrochi J, Montana CG (2007) Getting to the fat of the matter: models, methods and assumptions for dealing with lipids in stable isotope analyses. Oecologia 152:179-189

R Core Development Team (2015) R: A language and environment for statistical computing. R Foundation for Statistical Computing, Vienna

R Core Development Team (2017) R: A language and environment for statistical computing. R Foundation for Statistical Computing, Vienna

Rayner MJ, Carlile N, Priddel D, Bretagnolle V and others

Editorial responsibility: Kyle Elliott,

Sainte-Anne-de-Bellevue, Québec, Canada
(2016) Niche partitioning by three Pterodroma petrel species during non-breeding in the equatorial Pacific Ocean. Mar Ecol Prog Ser 549:217-229

Renner HM, Mueter F, Drummond BA, Warzybok JA, Sinclair EH (2012) Patterns of change in diets of two piscivorous seabird species during 35 years in the Pribilof Islands. Deep Sea Res II 65-70:273-291

Kenner HM, Drummond BA, Benson AM, Paredes R (2014) Reproductive success of kittiwakes and murres in sequential stages of the nesting period: relationships with diet and oceanography. Deep Sea Res II 109:251-265

* Renner M, Salo S, Eisner LB, Ressler PH and others (2016) Timing of ice retreat alters seabird abundances and distributions in the southeast Bering Sea. Biol Lett 12:20160276

* Sabarros PS, Durant JM, Grémillet D, Crawford RJM, Stenseth NC (2012) Differential responses of three sympatric seabirds to spatio-temporal variability in shared resources. Mar Ecol Prog Ser 468:291-301

Satterthwaite WH, Kitaysky AS, Mangel M (2012) Linking climate variability, productivity and stress to demography in a long-lived seabird. Mar Ecol Prog Ser 454:221-235

Schneider D, Hunt GL Jr (1984) A comparison of seabird diets and foraging distribution around the Pribilof Islands, Alaska. In: Nettleship DN, Sanger GA, Springer PF (eds) Marine Birds: Their Feeding Ecology and Commercial Fisheries Relationships. Proc Int Symp of the Pacific Seabird Group, Seattle, WA, Jan 1982. Canadian Wildlife Service Special Publication, p 86-95

* Schoener TW (1974) Resource partitioning in ecological communities. Science 185:27-39

* Scioscia G, Raya Rey A, Saenz Samaniego RA, Florentín O, Schiavini A (2014) Intra- and interannual variation in the diet of the Magellanic penguin (Spheniscus magellanicus) at Martillo Island, Beagle Channel. Polar Biol 37: 1421-1433

Sigler MF, Napp JM, Stabeno PJ, Heintz R, Lomas MW, Hunt GL Jr (2016) Variation in annual production of copepods, euphausiids, and juvenile walleye pollock in the southeastern Bering Sea. Deep Sea Res II 134:223-234

* Sinclair EH, Vlietstra LS, Johnson DS, Zeppelin TK and others (2008) Patterns in prey use among fur seals and seabirds in the Pribilof Islands. Deep Sea Res II 55: 1897-1918

Stabeno PJ, Kachel NB, Moorec SE, Napp JM, Sigler M, Yamaguchif A, Zerbini AN (2012) Comparison of warm and cold years on the southeastern Bering Sea shelf and some implications for the ecosystem. Deep Sea Res II 65-70:31-45

* Suryan RM, Kuletz KJ, Parker-Stetter SL, Ressler PH and others (2016) Temporal shifts in seabird populations and spatial coherence with prey in the southeastern Bering Sea. Mar Ecol Prog Ser 549:199-215

*Young HS, McCauley DJ, Dirzo R, Dunbar RB, Shaffer SA (2010) Niche partitioning among and within sympatric tropical seabirds revealed by stable isotope analysis. Mar Ecol Prog Ser 416:285-294

*Yurkowski DJ, Ferguson S, Choy ES, Loseto LL and others (2016) Latitudinal variation in ecological opportunity and intraspecific competition indicates differences in niche variability and diet specialization of Arctic marine predators. Ecol Evol 6:1666-1678

Zeppelin TK, Johnson DS, Kuhn CE, Iverson SJ, Ream RR (2015) Stable isotope models predict foraging habitat of northern fur seals (Callorhinus ursinus) in Alaska. PLOS ONE 10:e0127615

Submitted: June 23, 2017; Accepted: December 27, 2017

Proofs received from author(s): March 26, 2018 